\title{
沖縄本島都市域における熱収支の季節变化
}

\section{Seasonal Variation of the Heat Balance in the Urban Area of Okinawa Island}

\author{
下瀬 龍* \\ (琉球大学大学院理工学研究科) \\ Ryu SHIMOSE \\ Master of Engineering and Science in Physics and Earth Sciences, University of the Ryukyus. \\ 木村玲二** \\ （鳥取大学乾燥地研究センター） \\ Reiji KIMURA \\ Arid Land Research Center, Tottori University. \\ 石島 英*** \\ (琉球大学理学部物質地球科学科) \\ Suguru ISHIJIMA \\ Department of Physics and Earth Sciences, University of the Ryukyus.
}

In this study, the seasonal variation of the heat balance in the urban area of Okinawa Island is evaluated. First, the validity of a calculation method of the heat balance was examined by the comparison of surface temperature using an infrared thermometer and a calculation of the heat balance during winter, summer and early winter. The root-mean-squared error between the observed and calculated values of surface temperature was $1.1^{\circ} \mathrm{C}$.

The annual evaporation was estimated using an observational data of the measurement of flow rate of Hijya River basin in which the urban area occupies about $90 \%$ of the river basin. The annual evaporation from the year of 1984 to 1997 was $280 \pm 25$ $\mathrm{mm}$, while the average annual rainfall was $1877 \mathrm{~mm}$. Also, the annual evaporation and the heat balance components were estimated using a calculation method of the heat balance in the urban area of Okinawa Island. The averaged annual evaporation obtained for the years from 1989 to 1999 was $368 \pm 42 \mathrm{~mm}$, for which the average annual rainfall was $1988 \mathrm{~mm}$. The result of these estimations indicated that the annual evaporation in the urban area of Okinawa Island almost closed to constant value within the observed value of annual rainfall examined in this study. The averages of the annual surface temperature, sensible heat flux, and latent heat flux was $25.6^{\circ} \mathrm{C}, 52.3 \mathrm{Wm}^{-2}$ and $28.5 \mathrm{Wm}^{-2}$, respectively.

Key words : Heat balance, Urban area, Water balance

本研究では沖縄本島都市域における熱収支の季節変化について検討した. まず初めに, 熱収支計算の妥当性を冬, 夏, 初冬に行

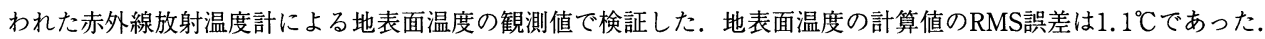

流域面積の約 $90 \%$ が都市で構成された比謝川流域の流出量デー夕を用いて，年蒸発量の算定をした．1984年から1997年までの年 蒸発量は平均年降水量 $1,877 \mathrm{~mm}$ に対して $280 \pm 25 \mathrm{~mm}$ であった。 さらに, 熱収支計算による沖縄本島都市域の年蒸発量と他の熱収支成 分を推定した. 1989年から1999年までの年蒸発量の計算值は平均年降水量1,988mmに対して368土42mmであった.これらの推定結果 より, 沖縄本島都市域における年蒸発量は本研究で扱った年降水量の範囲内ではほほ一定值に近づくことが示唆された. 平均年地 表面温度, 顕熱フラックス, 潜熱フラックスはそれぞれ $25.6^{\circ} \mathrm{C}, 52.3 \mathrm{Wm}^{-2}, 28.5 \mathrm{Wm}^{-2}$ であった.

キーワード : 都市域, 熱収支, 水収支

\section{I .はじめに}

日本の水文気象について, 水面, 森林, 芝生地で
の熱収支の研究が過去に行われている(近藤・桑 形, 1992 ; 近藤ら, 1992 ; 近藤・中園, 1993).これら の研究を進める目的として，広域陸面の熱収支の評

\section{*琉球大学大学院理工学研究科 $\overline{7} 903-0213$ 沖縄県中頭郡西原町字千原 1}

Master of Engineering and Science in Physics and Earth Sciences, University of the Ryukyus, Senbaru 1, Nishihara, Okinawa, 903-0213 Japan

**鳥取大学乾燥地研究センター $=680-0001$ 鳥取市浜坂 1390

Arid Land Research Center, Tottori University, Hamasaka 1390, Tottori, 680-0001 Japan

***琉球大学理学部物質地球科学科 $=903-0213$ 沖縄県中頭郡西原町字千原 1

Department of Physics and Earth Sciences, University of the Ryukyus, Senbaru 1, Nishihara, Okinawa, 903-0213 Japan 
価方法を確立するということがあげられよう．地表 面には水面, 裸地面, 植生面, 積雪面等があるため, 各地表面の熱収支特性を把握すべく研究が蓄積され ている.

しかしながら, 都市における熱収支, 特に季節変 化を再現する際には問題点を多く残している。理由 として, 都市特有の凹凸状態や熱容量等の複雑さが 熱収支計算の扱いを困難にしていることや，計算値 をどのような方法で検証すればよいか, つまり，都 市域における熱収支の観測方法が確立されていない ことなどがあげられよう。しかし，近年では神田ら (2000)によるシンチロメーターを利用した観測方法 が提案されている.

本研究の目的は熱収支式にバルク式を組み合わせ た計算方法 (1 次元モデル)を用いて, 都市域におけ る熱収支の季節変化を算定することである。まず初 めに, 熱収支の計算方法が都市域に適用できるかど うか考察を行った。 その際, 計算結果を検証する值 として，(1)沖縄本島北部の都市域を対象にした赤外 線放射温度計による地表面温度, (2)沖縄本島中南部 に位置する都市河川流量観測值による年蒸発量を使 用した。沖縄本島に注目した理由として，(1)では本 島北部の都市域の構造がそれほど複雑ではなく, 熱 収支計算の検証が比較的しやすいこと，(2)では，本 島中南部の都市河川が特徵的であることがあげられ る. 本研究で対象とした河川は沖縄本島中南部に位 置する都市河川で, 流域面積の約 $91 \%$ は市街地であ る.この河川のように流域が都市で始まるのは非常 に稀なので, 流出量がほほ都市域だけによるものと して信憑性があると考えられる，次に，熱収支計算 方法の検証結果を鑑み, 沖縄本島都市域に扔ける熱 収支の季節変化を考察する。

II 章では過去の研究で蓄積されてきた都市特有の パラメーターを参考にした熱収支の計算原理および 方法について述べる. IV 章では冬, 夏, 初冬に行わ れた航空機観測による地表面温度と熱収支計算によ る地表面温度との比較, そして都市河川の流量観測 によって得られた年蒸発量と熱収支計算による年蒸 発量の比較を行い, 熱収支計算法の有用性について 考察する，V章では，検証を行った熱収支計算法に よる沖縄本島都市域での熱収支の季節变化, VI章で は沖縄本島都市域での人工排熱量の影響について考 察する。

\section{II . 都市域における熱収支量の計算方法}

\section{1. 計算原理}

地表面における熱収支は次式で表される.

$(1-r e f) S^{\downarrow}+\varepsilon L^{\downarrow}=\varepsilon \sigma T_{s}^{4}+H+l E+G \quad$ (1)

ここに，refはアルベド， $S^{\downarrow}$ は日射量 $\left(\mathrm{Wm}^{-2}\right), \quad \varepsilon$ は地表面の射出率, $L^{\downarrow}$ は大気放射量 $\left(\mathrm{Wm}^{-2}\right), \sigma$ は ステファンボルツマン定数 $\left(=5.67 \times 10^{-8} \mathrm{Wm}^{-2} \mathrm{~K}^{-4}\right)$, $T_{s}$ は地表面温度 $\left({ }^{\circ} \mathrm{C}\right), H$ は顕熱フラックス $\left(\mathrm{Wm}^{-2}\right)$, $l E$ は潜熱フラックス $\left(\mathrm{Wm}^{-2}\right), G$ は地中伝導熱 $\left(\mathrm{Wm}^{-2}\right)$ である．都市域の熱収支を考える場合，(1) 式には人工排熱量が考慮されるが，正確な值を導き 出すのが困難なため, 本研究ではまず考慮しないで 熱収支計算を行う。人工排熱量の影響についてはVI 章で考察する。

$H$ とIEは次のバルク式で表される.

$$
\begin{aligned}
& H=c_{p} \rho C_{H} U\left(T_{s}-T\right) \\
& l E=l \rho C_{H} U \beta \quad\left\{q_{s a t}\left(T_{s}\right)-q\right\}
\end{aligned}
$$

ここに, $c_{p}$ は空気の定圧比熱 $\left(\mathrm{Jkg}^{-1} \mathrm{~K}^{-1}\right), \rho$ は空 気の密度 $\left(\mathrm{kgm}^{-3}\right), U$ は風速 $\left(\mathrm{ms}^{-1}\right), T$ は気温 $\left({ }^{\circ} \mathrm{C}\right), l$ は潜熱 $\left(\mathrm{Jkg}^{-1}\right), \beta$ は蒸発効率, $q$ は比湿 $\left(\mathrm{kgkg}^{-1}\right)$, $q_{s a t}\left(T_{s}\right)$ は $T_{s}$ に対する飽和比湿, $C_{H}$ は顕熱に対するバ ルク係数で, 大気安定度が中立の場合は次式で表さ れる。

$$
C_{H}=\frac{k^{2}}{\ln \left(\frac{z-d}{z_{0}}\right) \ln \left(\frac{z-d}{z_{T}}\right)}
$$

ここに, $k$ はカルマン定数 $(=0.4), z$ は $U$ の観測 高度 $(\mathrm{m}), d$ は地面修正量 $(\mathrm{m}), z_{0}, z_{T}$ は風速扔よび 気温に対する粗度長 $(\mathrm{m})$ である. 安定度が中立でな い場合は(4)式に安定度の関数を考慮する。

計算では日射量, 気温, 比湿, 風速, 降水量デー 夕(本研究では気象官署拉よびアメダスのデー夕)をイ ンプットし, 地表面温度, 顕熱フラックス, 潜熱フ ラックスを同時に求める.

\section{2. 計算方法}

木村ら (2001) は沖縄本島の各土地被覆(植生地, 水 面, 裸地面, 都市域)に上述の方法を適用し, 詳細な 日変化計算を行っている. 本研究でも, 航空機観測 による地表面温度と熱収支計算による地表面温度と の比較を行う際に, 各気象要素の日变化データ(1 時間㧍きのデータ)をインプットし, 詳細な日変化計 算を行った。ただし，解析の対象日は晴れた日であ り, 降雨日は対象としていない. 
熱収支量の日平均値は前節で得られた 1 時間おき の計算値を平均すればよいが，本研究では日平均気 象デー夕を利用する簡便な方法について提示する.

理由として，都市河川の流量観測によって得られた 年蒸発量と熱収支計算による年蒸発量の比較を行う 際に, 熱収支の日変化計算に用いる流域の降水量の 日変化を詳細に推定できないことがあげられる．日 降水量デー夕による計算誤差については後述する.

都市域における日蒸発量を $E_{d a y}(\mathrm{~mm})$ とすると, $E_{d a y}$ は次式のように降水中における蒸発量 $E_{i}(\mathrm{~mm})$, 降 水後の地面に保水された分の蒸発量 $S_{A}(\mathrm{~mm})$, 前日 に蒸発しきらなかった保水分の蒸発量 $R_{E}(\mathrm{~mm})$ に分 けられる。

$$
E_{d a y}=E_{i}+S_{A}+R_{E}
$$

降水中における蒸発量 $E_{i}$ は, 蒸発効率 $\beta$ を 1 日中 1 としたときの日蒸発量を $E_{\max }(\mathrm{mm})$ とすると,

$$
E_{i}=E_{\max }\left(\frac{\tau}{24}\right)
$$

で表される(近藤ら，1993）。ここに，ては降雨継続 時間 $(\mathrm{hr})$ で，日降水量を $\operatorname{Pr}(\mathrm{mm})$ とすると，

$$
\tau=18\left\{1-\exp \left(-\frac{P r}{12}\right)\right\}
$$

である(近藤ら，1992）.

降水後の地面に保水された分の蒸発量 $S_{A}$ は, 地面 の最大保水量を $S_{\max }(\mathrm{mm})$ とすると,

$$
\begin{aligned}
& S_{A}=S_{\operatorname{maxd}}\left\{1-\exp \left(-\frac{P r}{S_{\operatorname{maxd}}}\right)\right\} \\
& S_{\max d}=S_{\max }-R_{E}
\end{aligned}
$$

で表せる． $S_{\text {maxd }}$ は最大保水量から前日に蒸発しきれ ずに残った保水量を差し引いた值である。したがっ て, $R_{E}$ の有無に関わらず, $S_{A}+R_{E}$ の最大值は $S_{\text {max }}$ と なる. $S_{\text {max }}$ は近藤ら (1993)により $2 \mathrm{~mm}$ とした.

しかし, 地表面に遮断された降雨は気象条件によ り蒸発しきれないで地表面に残る可能性がある。 1 日に蒸発し得る蒸発量の限界值は, 蒸発効率 $\beta$ を 1 日中 1 としたときの日蒸発量 $E_{\max }$ である. そのため (5)式での日蒸発量 $E_{d a y}$ が $E_{\max }$ を上回ったときは,

$$
E_{d a y}=E_{\max }
$$

とし, その際, 蒸発しきれなかった残り $R_{E}$ は

$$
R_{E}=E_{d a y}-E_{\max }
$$

とし，翌日に残るとする。

以上の方法で日蒸発量を決定したのち，熱収支式 を解くことによって各熱収支成分（地表面温度，顕熱 フラックス)の日平均値を算定した。なお，計算に は名護気象官署および沖縄気象台のデー夕を用いた。
表ー 1 熱収支計算に用いるパラメーター

Table 1 Parameters required for a calculation method of the heat balance

\begin{tabular}{llll}
\hline Parameter & Value & Unit \\
\hline Albedo ref & 0.11 & $\cdots .$. \\
Moisture availability $\quad B$ & & 0 or 1 & $\ldots .$. \\
Thermal coefficient of the surface & $c \rho \lambda$ & $2.3 \times 10^{6}$ & $\mathrm{~J}^{2} \mathrm{~s}^{-1} \mathrm{~K}^{-2} \mathrm{~m}^{-4}$ \\
Zero plane displacement $\quad d$ & & 5.42 & $\mathrm{~m}$ \\
Roughness length for momentum & 20 & 1.11 & $\mathrm{~m}$ \\
Roughness length for sensible heat & $Z \mathrm{~T}$ & 0.001 & $\mathrm{~m}$ \\
\hline
\end{tabular}

\section{3．都市域におけるパラメーター}

表一 1 に都市域の熱収支計算で使われるパラメー ターについて示す.アルベドrefの值は神田ら （2000）を参考にし，0.11としたｒefは太陽高度の関 数であるが平均的に一定值を用いた．蒸発効率 $\beta$ は 降雨中やアスファルト，建物等による遮断水の蒸発 に要する時間の間は 1 とし，それ以外は 0 とした。

熱物理係数 $c \rho \lambda$ はコンクリートとアスファルトを 平均したものを想定した。しかし，熱物理係数の計 算に対する敏感度は比較的小さく，たとえその值が $1\left(\times 10^{6} \mathrm{~J}^{2} \mathrm{~s}^{-1} \mathrm{~K}^{-2} \mathrm{~m}^{-4}\right.$ ，アスファルトを想定 $)$ から $3(\times$ $10^{6} \mathrm{~J}^{2} \mathrm{~s}^{-1} \mathrm{~K}^{-2} \mathrm{~m}^{-4}$ ，コンクリートを想定）まで変化しても， 観測を行った時間帯での変動幅は約 $1{ }^{\circ} \mathrm{C}$ (地中伝導 熱では $\left.41 \mathrm{Wm}^{-2}\right)$ である。

地面修正量 $d$ や風速に対する粗度長 $z_{0}$ はMacdonald et al.(1998)による以下の算定式を用いて算出し た.

$$
\begin{gathered}
d=h\left\{1+4-\lambda_{p}\left(\lambda_{p}-1\right)\right\} \\
\lambda_{p}=\frac{A_{p}}{A_{d}} \\
Z_{0}=0.5 h \frac{A_{f}}{A_{d}}
\end{gathered}
$$

ここに, $h$ は建物の平均的高さ $(\mathrm{m}), A_{p}$ は対象領域 内にある建物の床面積, $A_{f}$ は対象領域内にある建物 の主風向に対する垂直方向の投影面積, $A_{d}$ は対象領 域内の面積である。本研究では解析する都市域(名 護市付近および都市河川流域内の市街地)の平均的な $h$ を $7 \mathrm{~m}$ とし， $A_{p}$ も住宅地図より平均的な值を算定し た $\left(A_{p} / A_{d}=0.5\right) . A_{f}$ はPetersen(1997) と同様に0.6 $6 A_{p}$ とした. 気温に対する粗度長 $z_{T}$ は不明確なパラメー ターの 1 つであるが，木村ら(2001)によると， ${ }_{T}$ の 都市域熱収支計算に対する敏感度はそれほど大きく ないことから，表に示した値を用いた。 


\section{III. 観測方法}

\section{1. 航空機に搭載した赤外線放射温度計による地 表面温度の観測}

本観測 (平成10年度文部省科学研究費, 課題番号 10660235)は沖縄本島北部全体の地表面温度を測定 することを目的に行われた。観測の詳細は木村ら (2001)を参照していただきたい.

観測は1999年 2 月 7 日(冬)，1999年 7 月 13日(夏), 1999年12月10日（初冬)の 3 回実施した。観測時間は, 2 月 7 日は 12 時36分〜 14 時18分, 7 月 13 日は 12 時 23 分〜14時06分，12月10日は12時23分〜14時11分であ る． 3 日ともに概ね晴天であったが，時おり直達日 射が雲で遮られている時間帯もあった１画像のス

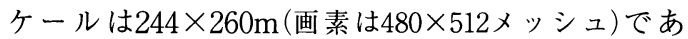
り，3 日ともに計108画像が解析対象である.

しかしながら，すべての画像に市街地(アスファ ルト，コンクリート等人工物も含む)が含まれている わけではなく，さらに航空機による観測は風の影響 などにより，毎回まったく同じ場所を飛ぶことはで きないので，3 日間の観測デー夕数には違いがある。 したがって，2月 7 日， 7 月13日，12月10日のデー 夕数はそれぞれ $18,12,21$ ( 1 つの熱画像内に存在す る市街地を抽出し, その平均值を 1 つのデータとしてい る)であった。解析対象市街地は, 本島北部の嘉陽, 川田, 辺野古, 名護, 与那, 呉我であるが, 平均的 に見ると建物の閉める割合はそれほど大きくなく， 建蔽率は50\%程度であった(前節参照)。

観測值には大気の透過率および地表面の射出率補 正を施した(木村ら，2001).

\section{2. 都市河川流量観測について}

本研究では流域のほとんどが市街地である都市河 川の比謝川に注目した，比謝川では沖縄開発庁によ る流量観測が1976年から行われており, 河川開発調 査水文観測報告書としてデータが残されている。

図一 1 に比謝川の位置, 流量観測場所, 流域面積 及び土地被覆状況を示す．沖縄中部を流れる比謝川 は沖縄市にその源流をもち，東シナ海へと流れ出る， 流量観測場所は比謝川中流部に位置し, 流域面積は $15.87 \mathrm{~km}^{2}$ である. 流域面積の約 $91 \%$ は市街地(アス ファルト，コンクリート等人工物も含む)で, 残りの約 $9 \%$ は畑, 森林, 荒地である。比謝川のように流域 が都市で始まる河川は非常に稀なので, 流出量がほ ぼ都市域だけによるものとして信憑性があると考え
られる。

流域からの年蒸発量は年降水量から年流出量を差 し引いて求めた，年流出量デー夕は，河川開発調查 水文観測報告書により, 観測機器が携帯型電磁流速 計(横河電子機器株式会社製, ES-7602・7603)を主に 使うようになった1984〜1997年のものである。ただ し，高水時には浮子測法による観測をしている．用 いたデータは測得率が99\%以上の年である。1990 年，1991年，1995年に関しては測得率が低いため解 析から除外した.

比謝川に人為的な水の流出があると, 比謝川流域 での正確な年流出量が把握できない. そのため, 比 謝川での人為的な流出となっているものを年流出量 から差し引かなければならない，流域内の下水道に ついて調べた結果, 家庭からの污水は污水管を通っ て具志川市にある浄水場まで運ばれ海に流されてい るため，流出量デー夕には直接関係しない。また， 污水管と雨水管は別となっており，雨水は直接比謝 川に放流されている．ただし，1箇所だけ小さな污 水処理場があったので，この污水処理場からの年流

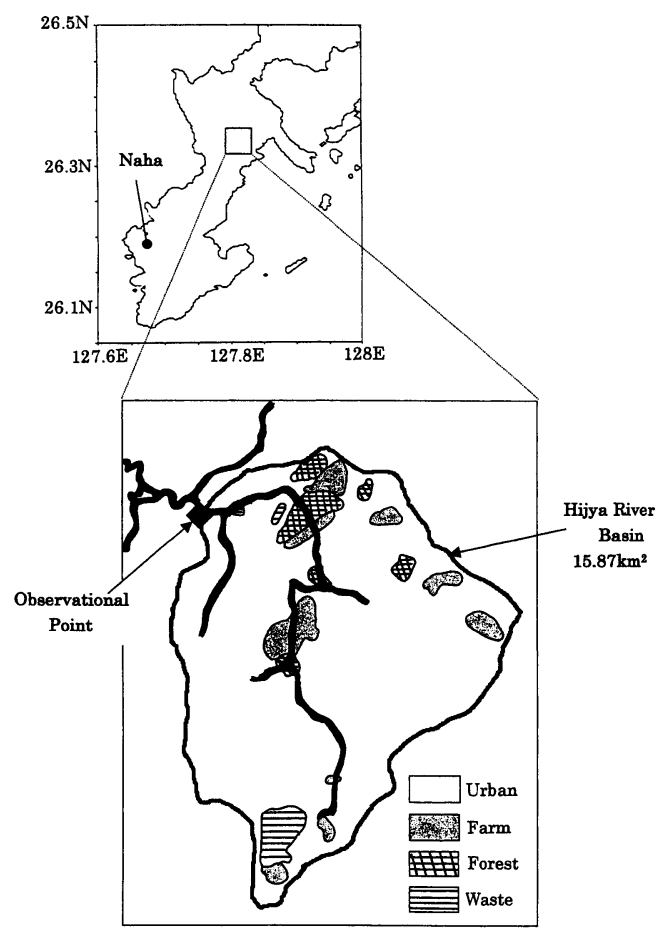

図一 1 比謝川流域と流域内の土地被覆

Fig. 1 The location of Hijya river basin and the land use classification within the river basin 
出量を差し引いたものを比謝川の年流出量とした. なお，污水処理場からの流出量は年流出量に換算す ると $3.9 \mathrm{~mm}$ であり，さほど大きな值ではない．流域 外からの下水管による雨水の給水はこの流域ではな かった。この流域は下水道普及率が低いという点で も研究対象として興味深い.

比謝川流域における年降水量は金武，読谷，胡屋 (コザ), 那覇, 系数の 5 地点の気象官署(またはアメ ダス)での年降水量を距離による加重平均で算定し た．その場合の基準点は流域の中心とした．本島中 部 (金武, 読谷, 胡屋) と南部 (那覇, 糸数)の年降水量 の差は約 $30 \mathrm{~mm}$ (10年平均)程度であり，また中南部の 標高は高くても $100 \mathrm{~m}$ 程度であるので地形の影響も さほど大きくはない. なお，中南部と北部の年降水 量の差は $500 \mathrm{~mm}$ 程度あるので北部地帯の年降水量に ついては解析から除外してある.

\section{IV . 熱収支計算法の検証結果}

\section{1. 赤外線放射温度計による地表面温度と熱収支} 計算による地表面温度との比較

赤外線放射温度計による地表面温度の観測值と熱 収支計算による計算値の比較を図一 2 に示す。

観測值について見てみると, 地表面温度の平均值 は 2 月 7 日， 7 月 13 日，12月 10 日でそれぞれ $24.8^{\circ} \mathrm{C}$, $46.5^{\circ} \mathrm{C}, 28.2^{\circ} \mathrm{C}$ で, 平均值からのばらつきの標準偏

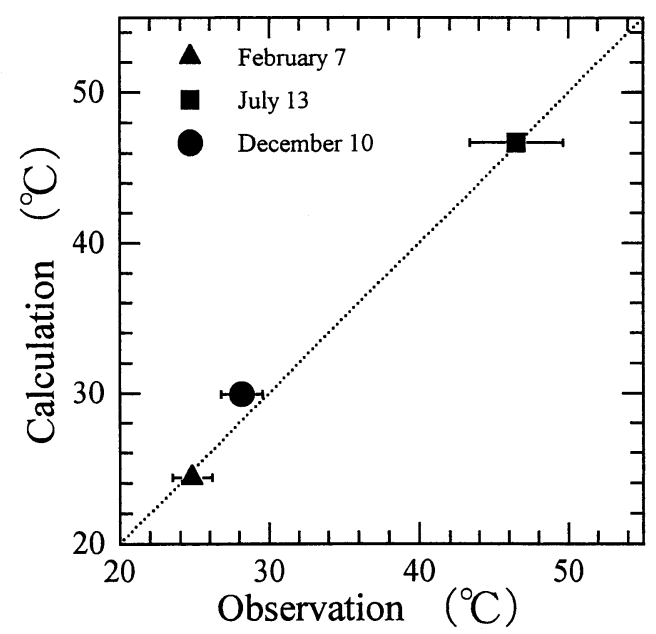

図一2 赤外線放射温度計による観測值と熱収支計 算による計算値との比較

Fig. 2 A comparison between the observed and calculated surface temperature using an infrared thermometer and a calculation method of the heat balance
差はそれぞれ $\pm 1.4^{\circ} \mathrm{C}, \pm 3.1^{\circ} \mathrm{C}, \pm 1.4^{\circ} \mathrm{C}$ あったた ばらつきの要因は, 建物の占める割合や人工物の構 成の違いによるためである.

熱収支計算による地表面温度は観測時間に近い 13 時，14時の計算值を平均したものである．地表面温 度の計算值は 2 月 7 日， 7 月13日，12月10日でそれ ぞれ $25.7^{\circ} \mathrm{C}, 46.7^{\circ} \mathrm{C}, 29.9^{\circ} \mathrm{C}$ であった。 なお，これ らの值は建物の建蔽率 $50 \%$, 平均高さ $7 \mathrm{~m}$, 表一 1 に示した粗度長等のパラメーターによって計算され た，全市街地を平均化したような值である。

2 月 7 日， 7 月 13 日の計算値は誤差の範囲内でよ く対応しているが，12月10日に関しては計算值より 観測值が若干低くなっている. 理由として, 本研究 ではアルベドの值を年間一定として扱っていること などが考えられるが，全体的に見ると季節を通して 熱収支計算による地表面温度の計算值は観測値を比 較的よく再現している(誤差 $\left.1.1^{\circ} \mathrm{C}\right)$ 。 なお，ここで は日中の地表面温度の観測值だけで本計算方法の検 証を行ったが，今後は日変化スケールの観測值で詳 細な検証を行う必要がある。

\section{2. 流域観測による年蒸発量と熱収支計算による 年蒸発量との比較}

図一 3 に流域観測 (1984年から1997年)による比謝 川流域の年降水量と年流出量, 年蒸発量の関係につ いて示す．年降水量 $P r_{y}$ と年流出量 $Q$ の関係は,

$$
Q=1.0903 P_{y}-449.6
$$

で表され(相関係数 0.85$), 1 ： 1$ の直線とほほ平行

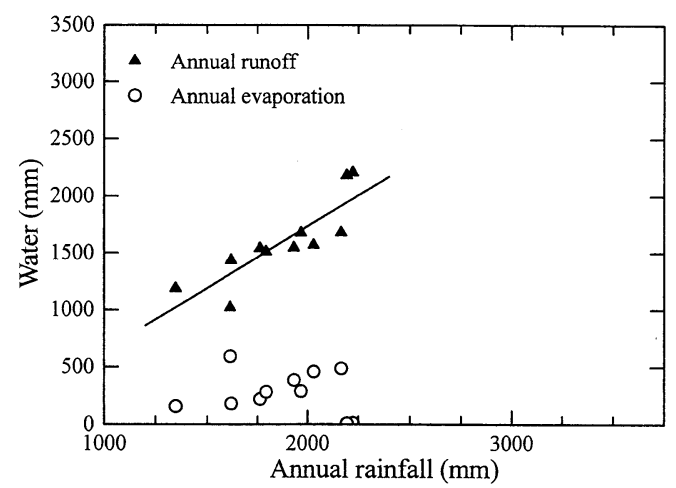

図一３比謝川流域の流量観測で得られた年降水量 と年流出量, 年蒸発量との関係

Fig. 3 Relationships among the annual rainfall, annual runoff, and annual evaporation, which were obtained from the measurement of flow rate of Hijya river basin 


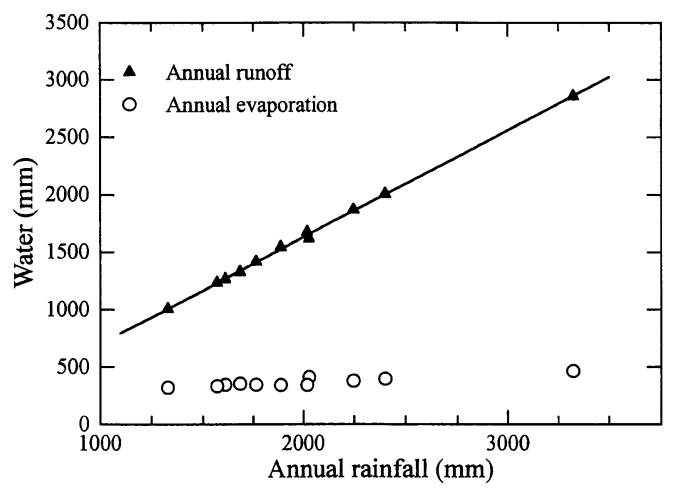

図一4 熱収支計算で得られた年降水量と年流出量, 年蒸発量との関係

Fig. 4 Relationships among the annual rainfall, annual runoff, and annual evaporation, which were obtained from a calculation method of the heat balance

になっているのが理解できる，一方，年降水量から 年流出量を差し引くことで算出した年蒸発量の 11 年 間平均値は $280 \mathrm{~mm}$ であり，平均值からのばらつきの 標準偏差は $\pm 189 \mathrm{~mm}$ と非常に大きい。そこで，相関 の高い(14)式が適用できると仮定すれば，年蒸発量 は，280土25mmとなり，ばらつきも小さくなる。つ まり, (14)式から判断すると, 本研究での降水量の観 測值の範囲内では比謝川流域における年蒸発量はほ ほ一定值に近づくと考えられる。多雨地域に存在す る森林流域ではこのような結果が認められているが, 都市流域においても同じような結果が得られたこと は興味媣い。

次に，図一 4 に熱収支計算による年降水量と年流 出量, 年蒸発量の関係について示す(1989年から1999 年までの計算結果)。年降水量と年流出量の関係は,

$$
Q=0.9291 P r_{y}-227.3
$$

で表される．熱収支モデルで算定した年蒸発量は， 年降水量がほほ同じ時でも違う場合がある。例えば, 図一 4 の降水量 $2,000 \mathrm{~mm}$ 付近の 2 つのプロットに注 目すると, 降水量の差は $11 \mathrm{~mm}$ であるが, 蒸発量の差 は69mmである．これは，降水日数30日の差に起因す ると考えられる．都市地表面が保有できる水の量は 限られているので, 年降水量が同じ場合, 降雨日数 が年蒸発量に影響を及ぼすようになる。11年間の蒸 発量の平均值は $368 \mathrm{~mm}$ で平均值からのばらつきの標 準偏差は $\pm 42 \mathrm{~mm}$ であった. (15)式から，蒸発量の計算 值は降水量や降雨日数の増大とともに増加するが, このばらつきの值が示すように，増加の割合は非常
に緩やかである。したがって，熱収支計算において も流域観測同様，本研究での降水量の観測值の範囲 内では，比謝川流域における年蒸発量はほぼ一定值 に漸近することが示唆された。

流域観測による年蒸発量は熱収支モデルによる年 蒸発量より $88 \mathrm{~mm}$ 少ない值になった，要因として，

(1)比較している年が若干違うこと．比較する年を 揃えると $80 \mathrm{~mm}$ の差，

(2)観測測器の誤差(業者によると士 $1 \%$ ．観測值よ り，最大で $23 \mathrm{~mm}$ 程度考えられる。），

(3)モデル計算では沖縄気象台のデー夕を用いたこ と,

などが考えられる，(3)については，木村(2001)によ ると, 那覇の年平均気温は比謝川流域の都市の年平 均気温に比べて約 $0.5^{\circ} \mathrm{C}$ 高いことが示されている. 実際に気温を $0.5^{\circ} \mathrm{C}$ 低くして計算を行った場合, 年 蒸発量は約 $20 \mathrm{~mm}$ 小さくる。これらの要因を総合的 に考慮しても，年間 $37 \mathrm{~mm}$ の誤差があるが，これは 1 日あたり $0.1 \mathrm{~mm}$ の量であり, 気象デー夕または熱収 支法の計算誤差の範囲内と考えられる。ここで, 蒸 発量の計算誤差を見るために敏感度テストを行う。 前にも述べたように，降水量推定值を流域付近の中 部(金武，読谷，胡屋)のみで算定した場合，南部も 含めた推定值よりも年降水量は約 $30 \mathrm{~mm}$ (1 日あたり $0.1 \mathrm{~mm})$ 小さくなる. そこで, 1 日あたり $0.1 \mathrm{~mm}$ 降水 量が多いと仮定して計算すると年蒸発量は $34 \mathrm{~mm}$ 増加 する．したがって，計算による年蒸発量の誤差は年 降水量の誤差と同程度であることが伺える. 次に蒸 発の計算で用いたパラメーターに注目する。(7)式中 の数值18は最大降雨継続時間であるが，これを 6 時 間増加させて計算すると年蒸発量は $44 \mathrm{~mm}$ 増加した。 また，最大保水容量 $S_{\text {max }}$ を $1.5 \mathrm{~mm}$ として計算した場合， 年蒸発量は $43 \mathrm{~mm}$ 減少した。したがって, これら気象 データとパラメーターによる年蒸発量の計算誤差は $\pm 40 \mathrm{~mm}$ 程度と考えられる. 計算による年間 $37 \mathrm{~mm}$ の誤 差は熱量に換算すると $3 \mathrm{Wm}^{-2}$ 程度であり，一般的 に言われている熱収支観測の誤差よりも非常に小さ いことも考慮すれば，本研究のような簡便な方法で も, ある程度の精度で年蒸発量を計算できることが 示された。

さて, 本研究で対象とした流域には市街地の他に 約 $7 \%$ の緑地が存在するため, 流域全体からの蒸発 量を考えるうえで,これらの存在を完全には無視で きないであろう．この゙わずかな緑地がもたらす年蒸 発量への影響については今後に譲りたい。 


\section{V．熱収支計算法による都市域熱収支の季節変 化}

ここでは，前章で検証した熱収支計算法を用いて， 沖縄本島都市域での熱収支の季節変化について考察 する。

図一 5 に熱収支計算による地表面温度, 顕熱 フ ラックス, 潜熱フラックスの季節変化(11年間平均) を示す. 参考のため, 日射量, 気温, 降水量の観測
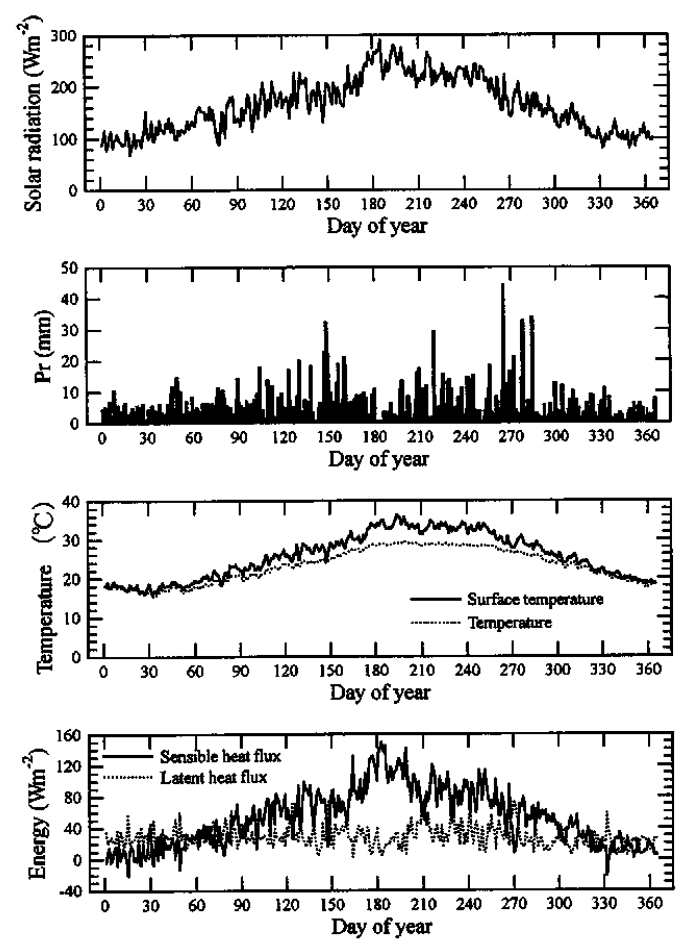

図一５日射量，降水量，気温，地表面温度，顯熱 フラックス、潜熱フラックスの季節変化 （1989年から1999年までの11年間平均値） 日 射量, 降水量, 気温は観測値, 地表面温度, 顕熱フラックス, 潜熱フラックスは熱収支計 算による計算値。

Fig. 5 The seasonal variation of the daily mean values of solar radiation, temperature, surface temperature, sensible heat flux, latent heat flux, and daily amount of precipitation (average values from the year of 1989 to 1999). The solar radiation, precipitation, and temperature are the observed values. while the surface temperature, sensible heat flux, and latent heat flux are the estimated values using a calculation method of the heat balance.
值 (沖縄気象台) も示す.

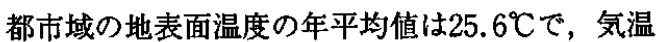
の $23.1^{\circ} \mathrm{C}$ よ $2.5^{\circ} \mathrm{C}$ 高い. 温度差の季節変化をみる と夏場が最も大きく $\left(5^{\circ} \mathrm{C}\right.$ 程度 $)$, 冬場は小さい。一 方，木村・石島 (1999) によると，沖縄本島北部森林 での地表面温度と気温の差は年間を通してほとんど 見受けられない。

都市域での顕熱フラックスの年平均値は52.3 $\mathrm{Wm}^{-2}$ であった，北部森林では顕熱フラックスの年 変動は小さく(年平均値は $\left.14 \mathrm{Wm}^{-2}\right)$, 夏場でも下向き のフラックスがあるのに対し，都市域では冬場のフ ラックスは小さく，夏場は大きいという季節変化が 認められた。また，わずかな期間(主に1，2月)で しか下向きのフラックスは認められない.

都市域での潜熱フラックスの年平均値は 28.5 $\mathrm{Wm}^{-2}\left(368 \mathrm{mmy}^{-1}\right)$ であった。 木村・石島 (1999)によ ると, 北部森林での潜熱フラックスの年平均值は $86.5 \mathrm{Wm}^{-2}\left(1,115 \mathrm{mny}^{-1}\right)$ で, 都市域ではその 3 分の 1 程度である、森林の潜熱フラックスは蒸散という 生理活動による季節変化があるのに対し，都市域の 潜熱フラックスの季節変化はその年の降雨量や降雨 日数の季節変化に直接関係するという特徴があ る．11年分を平均したため，潜熱フラックスが年間 を通じてほ泟一定であるように見える。沖縄本島で は，降雨量は主に梅雨期 $($ 梅雨入り，梅雨明けの平年 日day $=131 \sim 174)$ と台風期 $(8 \sim 9$ 月. day $=213 \sim$ 273)に集中するが, 冬場にも弱い降水があり，降雨 日数には季節変化が少ないためである.

ここで, 蒸発量の内訳を季節を通して考察する. 図一 6 に蒸発量の計算值の季節変化を示す $(1989$ 年 から1999年までの平均値)，年蒸発量 $368 \mathrm{~mm}$ のち, 降水中の蒸発量 $E_{i}$ は $178 \mathrm{~mm}$, 降水後の蒸発量 $E_{A}\left(=S_{A}\right.$ $\left.+R_{E}\right)$ は $190 \mathrm{~mm}$ である. 10 月から 5 月は降水中の蒸 発量より降水後の蒸発量が大きく，6月から 9 月は その逆である。これは主に気象状態の違いによると 考えられる.すなわち, 夏場は日射量や気温などが 高いため, 蒸発効率 $\beta$ を 1 日中 1 としたときの日蒸 発量 $E_{\max }$ が大きくなり, そのため降水中の蒸発量が 多くなる，また，継続的に降雨がある冬場の方が, 集中的に降雨がある夏場より, 直接流出が少なくな ることも大きな要因である. 図一6には前日に蒸発 しなかった保水量 $R_{E}$ を参考のために示している， $R_{E}$ が大きいということは地面が氷分を保持している時 間が長いことでもある。 $R_{E}$ の值は 1 月から 6 月に大 きく, 日射量や気温が高くなる夏場では蒸発量のポ 


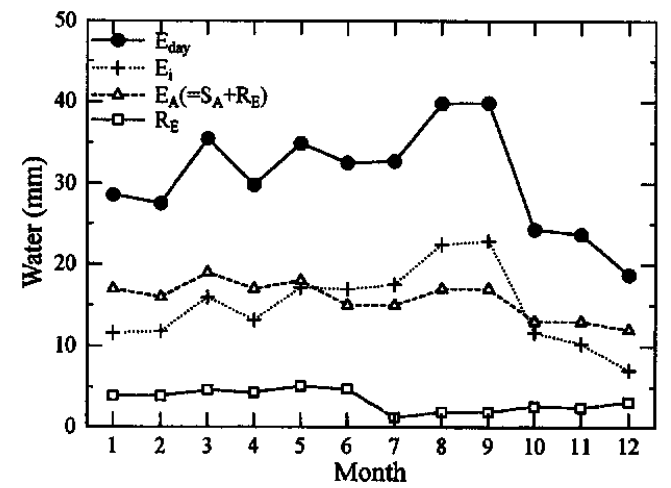

図一6 蒸発量の季節变化 $E_{\text {doy }}$ は絵蒸発量, $E_{i}$ は降 水中の蒸発量, $E_{A}$ は降水後の蒸発量, $R_{E}$ は前 日に残った保水量.

Fig. 6 The seasonal variation of the evaporation. $E_{d a y}$ is the total evaporation, $E_{i}$ the evaporation during the rainfall, $E_{A}$ the evaporation after the rainfall, and $\boldsymbol{R}_{\varepsilon}$ the residual water in the previous day.

テンシャルが大きくなるため，保水された水分はそ の日のうちに蒸発し， $R_{E}$ は小さくなる．また，前に も示したようにこの期間 ( 1 月から 6 月)は降雨日数 が多いことも要因の 1 つであり，夏場に比べると市 街地に扔ける保水効果があると言える。

以上，熱収支計算方法を用いて沖縄本島都市域で の熱収支の季節変化を検討した. 現段階ではこれら 熱収支の季節変化が本当に実態を表しているのかど うかは確認できない.しかし，都市域での熱収支季 節変化の全般的な傾向を見るためにも，計算による 補完は今後の都市域での熱収支の研究に必要である と考える.

\section{V. 人工排熱年の影雼}

都市域の熱収支を考える場合，(1)式には人工排熱 量を考慮するのが一般的である(一の瀬ら，1994）。 ここでは，本研究で対象とした都市流域の人工排熟 量について考察する.

木村 (2001)は, 都市と郊外の年平均気温差 $\Delta T \boldsymbol{T}_{\boldsymbol{w}-r}$ （K）を用いて都市域の年平均顕熱フラックス $H y_{*}$ $\left(\mathrm{Wm}^{-2}\right)$ を次式で表した.

$$
\begin{aligned}
& H y_{w}=H y_{r}+\Delta H y_{w-r} \\
& \Delta H y_{w-r}=\frac{1}{2} c_{p} \rho \frac{u \Delta T y_{u-r}^{2}}{\Gamma L}
\end{aligned}
$$

ここに, $H_{y}$ は郊外の年平均顥熱フラックス $\left(\mathrm{Wm}^{-2}\right)$, $\Delta H y_{x}$-rは都市と郊外の年平均顥熟フラックスの差, $c_{\rho}$ は空気の定圧比熱 $\left(\mathrm{Jkg}^{-1} \mathrm{~K}^{-1}\right), \rho$ は空気密度 $\left(\mathrm{kgm}^{-3}\right), u$ は都市における風速 $\left(\mathrm{ms}^{-1}\right), \Gamma$ は温位 傾度 $\left(\mathrm{Km}^{-1}\right) ， L$ は都市境界からの風下距離 $(\mathrm{m})$ であ る. 詳細な計算方法は木村 (2001)を参照されたい.

ここでは，都市流域に近い金武のアメダスデータ を用いて Hy を計算した，Hyrは木村・石島 (1999)に よる北部森林の計算結果から $14 \mathrm{Wm}^{-2}$ 引用し, 郊 外の年平均気温は奥のアメダスデータを用いた，奥 のデータを用いたのは周囲 $3 \mathrm{~km}$ がほほ森林で構成さ れているためである。(16)，(17)式より，都市流域に近 い金武における年平均影熱フラックスは $47 \mathrm{Wm}^{-2}$ と なる．参考程度に示すと那羁では $52 \mathrm{Wm}^{-2}$ である.

Hy山には土排熱も含まれていると考えられるが, 前章で求めた年平均顕熱フラックスが $52 \mathrm{Wm}^{-2}$ であ ることを考虑すれば，沖䋥本島の都市域における人 工排熱の影響はそれほど大きくないことが伺える。 都市で発生する人工排熱は日射量の数十パーセント に匹敵すると言われているが, 都市の気温上昇を説 明するのには問題点が多い(䊪原，2001）。今後は(16)， (17)式のような簡易モデルと詳細な熱収支モデルを組 み合わせて, 人工排熱の影響を検討することも有効 であると考える。

\section{VII. まとめ}

都市域における熱収支の季節変化を把握するため に，本研究では熱収支式にバルク式を組み合わせた 計算方法 (1 次元モデル)を用い,この計算方法の都 市域(沖縄本島都市域)に対する有用性および熱収支 の季節変化について考察した，以下に概要を示す。

(1)熟収支計算による地表面温度を, 赤外線放射温度

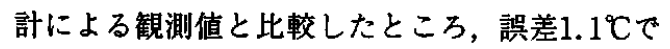
再現できた。

(2)流域面積の $90 \%$ 以上が市街地で占められる沖縄本 島の都市河川である比謝川流域の流量観測によっ て算定した年蒸発量は $280 \pm 25 \mathrm{~mm}$ であった(1984〜 1997年)。また，熱収支計算による年蒸発量は368 $\pm 42 \mathrm{~mm}$ であった(1989 1999年)。これらの結果よ り, 本研究で扱った年降水量の䈖囲内では，年蒸 発量はほほ一定値に渐近することが示唆された。 観測値と計算値の差は $37 \mathrm{~mm}$ 程度あるが, 敏感度テ ストにより気象データやパラメーターの誤差で士 $40 \mathrm{~mm}$ 程度年蒸発量の計算に誤差が生じることを示 した.

(3)熟収支計算により，沖縄本島都市域における熱収 支の季節変化がどのような特幑を持つか検討した。 
都市域の地表面温度の年平均値は $25.6^{\circ} \mathrm{C}$ で, 気温 より $2.5^{\circ} \mathrm{C}$ 高い．温度差の季節変化をみると夏場 が最も大きく ( 5 C程度)，冬場は小さかった。都 市域での顕熱フラックスの年平均値は $52.3 \mathrm{Wm}^{-2}$ であり，北部森林の $14 \mathrm{Wm}^{-2}$ に比べて非常に大き いことを示した．都市域での潜熱フラックスの年 平均値は $28.5 \mathrm{Wm}^{-2}\left(368 \mathrm{mmy}^{-1}\right)$ であった。顕熱フ ラックスほどの明瞭な季節変化は見られないが, 潜熱フラックスの季節変化は降雨量や降雨日数の 季節変化と関係があることを示した.

(4)本研究で対象とした都市流域では，人工排熱の影 響は小さいことが示された。

今後は降水量の日変化も考慮した詳細な熱収支の 日変化計算も行い，本研究で用いた簡便な方法との 比較を行う。そして，日本各地の都市にもこれらの 方法を適用し，都市域に扮ける熱収支の実態把握に 努める必要がある。

\section{參费文献}

一の瀬俊明・花木啓祐・松尾友矩 (1994)：細密地理 情報にもとづく都市人工排熱の時空間分布の構造 解析, 環境工学研究論文集, 31，263-273.

神田学・森脇亮・鈴木譲 $(2000)$ ：住宅街の接地境界

層における乱流フラックスの実測 一シンチロ メーターの利用一, 天気, 47, 453-462.

木村玲二 (2001)：沖縄本島における気候の特徽と人 工的因子が各地の気温に及ほす影響について，農 業気象, 57(3)，(印刷中).
木村玲二・石島 英(1999)：沖縄本島北部地域森林 地帯からの蒸発散量の試算, 琉球大学理学部紀 要, $68,13-21$.

木村玲二・石島 英・横山拓哉(2001)：赤外線放射 温度計による地表面温度と熱収支モデル計算によ る地表面温度の比較，天気，48，371-382.

近藤純正・桑形恒男 (1992)：日本の水文気象(1)：放 射量と水面蒸発，水文·水資源学会誌，5(2)，13 -27 .

近藤純正 -中園 信 - 渡辺 力(1992) : 日本の水文 気象(1)：森林における降雨の遮断蒸発量, 水文・ 水資源学会誌， 5(2)，29-36.

近藤純正・中園 信 (1993)：日本の水文気象(4)：地 域代表風速, 熱収支の季節変化, 舖装地と芝生地 の蒸発散量, 水文·水資源学会誌，6(1)，9-18.

Macdonald, R.W., R.F. Griffiths and D.J. Hall (1998) : An improved method for the estimation of surface roughness of obstacle arrays, Atmos. Environ., 32(11), 1857-1864.

Petersen, R.L. (1997) : A wind tunnel evaluation of methods for estimating surface roughness length at industrial facilities, Atmos. Environ., 31, 45-57.

榊原保志 (2001)：都市表面からの顕熱供給と都市大 気の混合が夜間ヒートアイランド形成に与える影 響の比較, 天気, 48(5)，305-311.

(受付：2001年 3 月 26 日, 受理：2001年10月 12 日) 